\title{
DOMINIKA DZWONKOWSKA
}

Instytut Ekologii i Bioetyki, UKSW, Warszawa

\section{Zmiany klimatu a zrównoważona turystyka - płaszczyzna etyczna ${ }^{1}$}

Słowa kluczowe: zrównoważony rozwój, turystyka, zrównoważona turystyka, zmiany klimatu, etyka środowiskowa, aksjologia

Key words: sustainable development, tourism, sustainable tourism, climate change, environmental ethics, axiology

\section{SUMMARY}

\section{Climate change and sustainable development - the ethical dimension}

Tourism is one of the fastest developing sectors of the economy and one of the sectors extremely vulnerable to climate change. As all tourism destinations rely on their unique natural or cultural values, any changes in climate and an increase in extreme climate events impact on the industry more than the other economic sectors. The article presents the relationship between climate change and tourism, focusing on the ethical dimension of sustainable tourism. The aim of the article is to present the moral questions on sustainability in tourism in the context of climate change. It focuses on environmental values and presents its role in the context of sustainable tourism development.

Artykuł jest rozbudowaną i uaktualnioną wersją artykułu Zmiany klimatu a zrównoważona turystyka (Wybraniec - profesjonalny kwartalnik radnego (2013)1, ss. 42-46). 


\section{Wstęp}

Turystyka jest sektorem gospodarki, który jest powiązany siecią zależności ze środowiskiem naturalnym. Z jednej strony każda atrakcja turystyczna opiera się na wykorzystaniu wyjątkowych walorów środowiskowych bądź kulturowych, z drugiej jednak strony dopuszczenie nadmiernego ruchu turystycznego w obszarach cennych przyrodniczo prowadzi do nieuchronnej ich degradacji i zniszczenia. Stąd w turystyce w sposób szczególny pojawia się pytanie jak zabezpieczyć posiadane zasoby oraz zapewnić ich trwałość i możliwość korzystania z nich jak najdłużej. Jednym ze scenariuszy działań mających na celu zapewnienie długotrwałego i rozsądnego korzystania z zasobów jest implementacja zasady zrównoważonego rozwoju do turystyki. Zasada zrównoważonego rozwoju uwzględnia nie tylko rozwój ekonomiczny, ale także poszanowanie dóbr środowiska naturalnego i troskę o zabezpieczenie interesów społecznych. W taki sposób sektor turystyczny stara się dążyć do rozwoju uwzględniając nie tylko rachunek ekonomiczny, ale również aspekt środowiskowy i społeczny.

Wprowadzanie zasady zrównoważonego rozwoju jako doktryny ekonomicznej wynika $z$ dostrzeżenia zagrożeń stwarzanych przez obecne podejście do rozwoju gospodarczego. Wykładniczy wzrost populacji i związane z tym coraz większe zużywanie zasobów stwarza zagrożenie dla ekosystemu ziemskiego tym samym stając się niebezpiecznym nie tylko dla środowiska przyrodniczego, ale i dla zdrowia oraz przyszłego istnienia populacji ludzkiej. Próby implementacji zasady zrównoważonego rozwoju wynikają nie tylko $\mathrm{z}$ racjonalnej analizy stanu naszego środowiska. Jest to przede wszystkim próba wykorzystania narzędzi ekonomicznych, prawnych i politycznych do rozwiązywania problemów społecznych, gospodarczych oraz środowiskowych zarówno w skali regionalnej, narodowej jak i globalnej.

W niniejszym artykule została podjęta próba analizy wpływu zmian klimatu na rozwój turystyki. Temat ten jest bardzo obszerny i zaczyna być coraz szerzej dyskutowany w specjalistycznej literaturze naukowej, 
w artykule został on ukazany z uwzględnieniem płaszczyzny etycznej. Zrównoważona turystyka jest odpowiedzią nie tylko na powiększającą się antropopresję, ale także jest sferą realizowania wartości etycznych i dostrzegania moralnych zobowiązań człowieka wobec środowiska przyrodniczego i społecznego, co zostało zarysowane w niniejszym artykule.

\section{Zrównoważona turystyka}

Gwałtowny rozwój sektora usług turystycznych oraz osiągnięcie liczby turystów na poziomie 1,035 miliarda turystów w roku 2012 (Web-04) skłoniły do analizy działań podejmowanych w tym sektorze i przyczyniły się do zintensyfikowanych działań na rzecz wprowadzenia zrównoważonej turystyki. Problem ten podejmowano wielokrotnie, a w roku 1995 zaledwie trzy lata po Szczycie Ziemi w Rio de Janeiro opracowano kodeks zasad dla ruchu turystycznego. Światowa Rada Podróży i Turystyki oraz Światowa Organizacja Turystyki² wspólnie z Radą Ziemi opracowały tzw. „Agendę 21 dla Podróży i Przemysłu Turystycznego”. Wśród priorytetowych zadań wymieniono tam następujące:

- „turystyka powinna propagować zdrowy i produktywny tryb życia w harmonii z przyrodą, zbliżać do siebie ludzi różnych narodowości, kreować otwartość i tolerancję;

- rozwój turystyki ma przyczyniać się do zachowania zasobów przyrody oraz ochrony rdzennej kultury społeczności lokalnych;

- rozwój turystyki w regionach powinien dokonywać się przy udziale ludności miejscowej począwszy od etapu planowania; powinien kreować nowe źródła dochodów ludności miejscowej;

2 Światowa Organizacja Turystyki (ang. United Nations World Tourism Organization - UNWTO) powstała w 1975 roku, obecnie zrzeszonych jest w niej 155 państw. UNWTO jest agendą ONZ odpowiadającą za promowanie odpowiedzialnego i zgodnego z zasadami zrównoważonego rozwoju turyzmu. Jako wiodąca organizacja turystyczna promuje rozwój turystyki zapewniający wzrost ekonomiczny, rozwój społeczny oraz trwałość zasobów przyrodniczych. 
- działalność usługowa i produkcyjna w branży turystycznej powinna zmierzać do zmniejszenia ilości odpadów oraz oszczędności energii i wody, eliminować z użycia substancje niebezpieczne dla środowiska, stymulować personel, klientów i społeczności lokalne do zachowań proekologicznych itp.;

- kraje powinny promować politykę otwartego systemu rynkowego w turystyce, wolną wymianę usług turystycznych, podporządkowaną zasadom zrównoważonego rozwoju i respektującą międzynarodowe prawo ochrony środowiska" (Zaręba 2010: 38-39).

Zasady te stały się podstawą do realizowania zrównoważonego rozwoju w turystyce oraz troski o to, aby sektor turystyczny mógł jak najlepiej się rozwijać w sposób uwzględniający powiązania sfery ekonomicznej ze sferą społeczną i środowiskową. Zagrożeniem dla prowadzenia działalności turystycznej jest wyczerpywanie się zasobów i niszczenie walorów środowiska, z których korzysta wielu operatorów turystycznych. Zjawisko to opisał Garrett Hardin określając je wiele mówiącą nazwą „tragedia dóbr wspólnych” lub „tragedia wspólnego pastwiska”. Zjawisko to jest związane z korzystaniem z danego obszaru i eksploatowaniem jego zasobów w sposób niekontrolowany przez wielu użytkowników. Operatorzy turystyczni nie kontrolując ilości turystów, niekiedy doprowadzają do tego, że w sezonie na danym obszarze pojawia się liczba turystów przekraczająca możliwości środowiska naturalnego. W wyniku tego obszar o unikalnych walorach przyrodniczych jest nadmiernie eksploatowany i stopniowo niszczony.

\section{Zmiany klimatu a turystyka}

Wszystkie atrakcje turystyczne opierają się na wyjątkowych walorach przyrodniczych bądź kulturowych danego obszaru, stąd mądre gospodarowanie tym wspólnym dobrem jakim jest przyroda powinno być jednym z kluczowych aspektów branych pod uwage przy planowaniu działalności turystycznej. Jednak unikalne walory przyrodnicze atrakcji turystycznych mogą ucierpieć nie tylko w skutek nadmiernej 
eksploatacji zasobów, ale również w wyniku zmian klimatycznych. Zmiany klimatyczne przejawiające się jako coraz częstsze występowanie ekstremalnych zjawisk pogodowych, problemy z nadmiarem lub brakiem wody, pożary, przemieszczanie się gatunków roślin i zwierząt wywołane zmianą warunków atmosferycznych oraz innymi zjawiskami powiązanymi z klimatem. Wszystkie wyżej wymienione zjawiska stanowią istotne zagrożenia dla stanu i zachowania walorów turystycznych.

Jednym z sektorów znacząco wpływających na zmiany klimatu jest transport, w turystyce 75\% całkowitej emisji ditlenku węgla pochodzi właśnie z transportu (Mishev, Mochurova 2010: 194). Turyzm oferując podróże do atrakcji turystycznych oddalonych od miejsca zamieszkania, staje się jednym ze znaczących emitentów, co więcej prognozy przewidują dalszy wzrost emisji z transportu i rozwój sektora usług turystycznych. Jednak mimo negatywnego wpływu na klimat turystyka nie stanowi aż tak dużego zagrożenia jak inne sektory. Według badań UNWTO turyzm wprawdzie odpowiada za zaledwie 5\% emisję ditlenku węgla, co w porównaniu z innymi sektorami jak na przykład z rolnictwem z 15\% emisją jest mało znaczącym zagrożeniem dla środowiska (Mishev, Mochurova 2010: 194). Turyzm mimo znaczącej emisji i przewidywanego wzrostu oddziaływania na klimat, jest sektorem, który raczej jest poszkodowany przez zmiany klimatu niż przyczynia się do nich.

Turyzm jest jednym z sektorów wyjątkowo zagrożonych skutkami zmian klimatu. Prowadzone dotychczas badania naukowe w zakresie wpływu zmian klimatu na turystykę prognozują zmianę w lokalizacji atrakcji turystycznych po roku 2030. Przewiduje się, że w skutek zmian klimatu część z dotychczas atrakcyjnych turystycznie terenów nie będzie tak chętnie odwiedzana, ale pojawią się nowe rejony, których klimat zmieni się na tyle, że stanie się atrakcyjny dla turystów. Na przykład badania przeprowadzone przez Bigano i współpracowników (Bigano i in 2006) sugerują, że najbardziej skorzysta na tym Azja, która przejmie większy udział w rynku usług turystycznych (tamże: 11). Po- 
wyższe analizy doprowadziły badaczy do stwierdzenia, że poszczególne kraje mogą doświadczyć gwałtownych zmian w ilości turystów. Przewiduje się, że kraje chłodniejsze spotka wzrost ilości turystów z własnego kraju, podczas gdy w krajach cieplejszych nastąpi spadek krajowej turystyki. W niektórych przypadkach ilości osób korzystających z usług oferowanych przez turyzm mogą wzrosnąć znacząco jak w przypadku Mongolii o 100\% lub spaść jak np. w Mali o 30\%. Wyjątkiem od powyższej reguły będą kraje położone wyżej nad poziomem morza otoczone przez kraje położone niżej, gdyż mimo, że są chłodniejsze od otaczających je państw, to dotkną je zjawiska takie same jak w krajach cieplejszych. Mimo spadku ilości turystów przyjeżdżających z odległych państw, kraje te mogą okazać się atrakcyjne dla turystów z sąsiednich, cieplejszych państw (tamże).

Zmiany klimatu wpływają także na międzynarodową turystykę, przyczyniając się do maksymalnego spadku o 10\% poniżej prognozowanej ilości turystów w porównaniu z modelami nie uwzględniającymi zmian klimatu w roku 2025 i ilością turystów zmierzającą do zera po tym roku. Ilość podróży międzynarodowych spadnie dlatego, że część turystów będzie wolała spędzać wakacje w swoim kraju, szczególnie dotyczy to turystów z Niemiec i Wielkiej Brytanii, którzy stanowią znaczący odsetek turystów odbywających podróże międzynarodowe. Biorąc pod uwagę poszczególne państwa liczba turystów zagranicznych może spaść o $60 \%$ bądź wzrosnąć nawet do $220 \%$.

Powyższe badania jednoznacznie wskazują wpływ zmian klimatu na rozwój sektora turystycznego, zostało w nich wykazane, że zmiany klimatu przyczynią się do podniesienia atrakcyjności krajów zimnych oraz obniżenia walorów turystycznych krajów ciepłych. Należy jednak zauważyć, że w przypadku ocieplania się klimatu może nastąpić również bezpowrotna utrata niektórych atrakcji turystyki zimowej. Dodatnie temperatury w okresie sezonu sportów zimowych, przyczynią się do utraty walorów danego obszaru i mogą prowadzić do zamykania ośrodków turystyki zimowej. Badanie Koening i Abegg pokazują, że ośrodki narciarskie położone na niższych wysokościach w Szwajcarii 
odnotowały straty wynikające z ocieplania się klimatu (Koening, Abegg 1997). Naukowcy zbadali pokrywę śnieżną przyjmując jako punkt wyjścia założenie, że ilość śniegu odpowiednia do uprawiania sportów zimowych powinna pokrywać trasy narciarskie przez sto dni w roku, od początku grudnia do końca kwietnia. Analizy wykazały, że kurorty położone powyżej 1.200 metrów nad poziomem morza spełniły tę zasadę, problem niewystarczającej ilości śniegu dotknął jednak kurorty położone poniżej tej wysokości. Jest to istotne zagrożenie, prognozy pokazują, że wzrost temperatury o $2^{\circ} \mathrm{C}$, może doprowadzić do przesunięcia granicznej wysokości o 300 metrów, a w konsekwencji doprowadzi to do utracenia nawet $63 \%$ obszarów turystyki zimowej. Stanowi to znaczące zagrożenie dla gospodarki regionów, które czerpią dochody z turystyki zimowej.

Utrata pokrywy śnieżnej nie jest jedyną konsekwencją zmian klimatu, pojawiają się tutaj także inne zagrożenia chociażby związane z występowaniem klęsk żywiołowych czy katastrof ekologicznych. Na przykład wyciek ropy w Zatoce Meksykańskiej przyczynił się do utraty walorów krajobrazowych tych obszarów, zatrucia ekosystemów i co za tym idzie ogromnymi stratami w turystyce. Europejska Agencja Środowiskowa (EEA 2007 i 2011) ostrzega również przed okresowymi problemami wynikającymi z braku wody czy niskiej jakości bądź ryzykiem skażenia wody (pitnej lub wód w kąpieliskach), a także przed zagrożeniem dla bioróżnorodności. Między innymi przesuwanie się występowania siedlisk niektórych gatunków roślin czy zwierząt może powodować utratę walorów przyrodniczych regionu, ale także sama turystyka jest zagrożeniem dla istnienia niektórych gatunków roślin i zwierząt. Poważnym zagrożeniem jest również niefrasobliwe podejście turystów do kwestii sprowadzania gatunków obcych, brak wiedzy o zagrożeniach wynikających z introdukcji inwazyjnych gatunków obcych często jest przyczyną wprowadzania nie rodzimych gatunków do środowiska, co może mieć poważne konsekwencje i prowadzić do zagrożenia istnienia gatunków rodzimych. 
Obok wspomnianych zagrożeń istotne znaczenie ma także rosnąca urbanizacja obszarów atrakcyjnych turystycznie. Rozwój turystyki stymuluje rozwój infrastruktury i budownictwa w miejscach atrakcji turystycznych. W związku $\mathrm{z}$ tym wzrasta tam antropopresja na środowisko naturalne, na przykład w postaci urbanizacji terenów o wysokich walorach przyrodniczych, zwiększonego zużycia wody i produkcji odpadów, fragmentacji siedlisk oraz utraty bioróżnorodności. Te i inne zagrożenia wynikające $\mathrm{z}$ racji postępujących zmian klimatu i rozwoju turystyki stają się przyczyną rozwijania badań w zakresie klimatologii turystyki (ang. tourism climatology) (de Freitas 2003). Klimat jest jednym z zasobów w oparciu, o które prowadzona jest działalność turystyczna i wszelkie zmiany w tym zakresie, zarówno w postaci ekstremalnych zjawisk pogodowych jak i stopniowego zmieniania się klimatu, mają wpływ na walory danej atrakcji turystycznej. Stąd wzorem innych dyscyplin, dla których zmiany klimatu mogą stanowić zagrożenie również badacze turystyki podjęli analizy w tym zakresie. Szczególnym zagrożeniem dla turystyki są ekstremalne zjawiska pogodowe i katastrofy naturalne. Niemniej zmiany klimatu w turystyce mogą być odczuwane w 3 aspektach, w sferze estetycznej, fizycznej i termalnej. De Freitas przybliża przykłady, znaczenie i wpływ poszczególnych zjawisk klimatycznych występujących w turystyce:

\begin{tabular}{|c|c|c|}
\hline Obszar klimatu & Znaczenie & Wplyw \\
\hline \multicolumn{3}{|c|}{ Estetyczne } \\
\hline $\begin{array}{l}\text { nasłonecznienie/ } \\
\text { zachmurzenie }\end{array}$ & jakość doświadczenia & zadowolenie, atrakcyjność miejsca \\
\hline widoczność & jakość doświadczenia & zadowolenie, atrakcyjność miejsca \\
\hline długość dnia & komfort & $\begin{array}{l}\text { ilość godzin z dostępem do światła } \\
\text { słonecznego }\end{array}$ \\
\hline \multicolumn{3}{|l|}{ Fizyczne } \\
\hline wiatr & rozdrażnienie & $\begin{array}{l}\text { porwane przez wiatr rzeczy, piasek, } \\
\text { kurz }\end{array}$ \\
\hline deszcz & rozdrażnienie, urok & $\begin{array}{l}\text { moknięcie, mniejsza widoczność } \\
\text { i zadowolenie }\end{array}$ \\
\hline
\end{tabular}


Zmiany klimatu a zrównoważona turystyka...

\begin{tabular}{|c|c|c|}
\hline śnieg & $\begin{array}{l}\text { sporty zimowe/ } \\
\text { aktywność }\end{array}$ & udział w sportach/aktywności \\
\hline lód & niebezpieczeństwo & $\begin{array}{l}\text { uszkodzenie zdrowia, zniszczenie } \\
\text { własności }\end{array}$ \\
\hline $\begin{array}{l}\text { surowe warunki } \\
\text { atmosferyczne }\end{array}$ & $\begin{array}{l}\text { rozdrażnienie, } \\
\text { niebezpieczeństwo }\end{array}$ & wszystkie wymienione powyżej \\
\hline jakość powietrza & $\begin{array}{l}\text { rozdrażnienie, } \\
\text { niebezpieczeństwo }\end{array}$ & zdrowie, dobrostan fizyczny, alergie \\
\hline $\begin{array}{l}\text { promieniowanie } \\
\text { ultrafioletowe }\end{array}$ & $\begin{array}{l}\text { niebezpieczeństwo, } \\
\text { atrakcyjność }\end{array}$ & $\begin{array}{l}\text { zdrowie, opalenizna, poparzenia } \\
\text { słoneczne }\end{array}$ \\
\hline \multicolumn{3}{|c|}{ Termalne } \\
\hline $\begin{array}{l}\text { połączone } \\
\text { oddziaływanie } \\
\text { temperatury } \\
\text { powietrza, wiatru, }\end{array}$ & komfort termalny & $\begin{array}{l}\text { stres środowiskowy, napięcie } \\
\text { fizjologiczne, hipotermia, hipertermia }\end{array}$ \\
\hline $\begin{array}{l}\text { promieniowania } \\
\text { słonecznego, } \\
\text { wilgotności, } \\
\text { promieniowanie } \\
\text { długofalowe. }\end{array}$ & $\begin{array}{l}\text { terapeutyczny, } \\
\text { wzmacniający }\end{array}$ & warunki do rekonwalescencji \\
\hline
\end{tabular}

Tabela 1. Czynniki klimatyczne, w których klimat wpływa na turystykę. Źródło: de Freitas 2003: 49, tłumaczenie własne.

Przedstawiono w tabeli obszary oddziaływania klimatu, które mogą mieć wpływ na rozwój turystyki i powinny być brane pod uwagę przy planowaniu działalności w sektorze turystyki. Wskaźnik klimatyczno-turystyczny (TCI) zwyczajowo uwzględnia tylko miesięczne uśrednione wartości takich wskaźników meteorologicznych jak na przykład: temperatura powietrza, wilgotność czy opady. Biorąc pod uwagę powyżej wymienione czynniki TCI powinno opierać się na szerszej analizie i uwzględniać trzy wyżej wymienione aspekty oddziaływania warunków atmosferycznych na człowieka. Wtedy systemowe wdrażanie zrównoważonej turystyki będzie dużo bardziej skuteczne i holistyczne.

Chociaż wydaje się, że wprowadzenie zmian w obszarze turystyki jest bardzo trudne to nie jest to niemożliwe, ciekawym przykładem 
zastosowania zasad zrównoważonego rozwoju dla rozwoju regionu i wzmocnienia jego atrakcyjności turystycznej jest przykład Szczawnicy. Szczawnica jest miejscowością uzdrowiskową stąd jakość środowiska jest szczególnie ważna zarówno dla władz jak i dla mieszkańców gminy. Mając to na uwadze władze Szczawnicy w 2007 roku zaczęły starania, aby zamontować ok. 2000 kolektorów słonecznych do ogrzewania wody. Pomysł ten spotkał się z dużym zainteresowaniem społeczeństwa. W celu realizacji tej inicjatywy powołano Stowarzyszenie na Rzecz Ekorozwoju Szczawnicy „EKO Szczawnica”, do którego przystąpiło ponad 400 osób. Wkrótce podjęto też działania na rzecz zdobycia środków na realizację tego przedsięwzięcia. Wsparcie uzyskano od Wojewódzkiego Funduszu Ochrony Środowiska i Gospodarki Wodnej, który przyznał pożyczkę w wysokości 3473000 zł, oprocentowaną w skali 4\%, z możliwością jej umorzenia w wysokości 35\% oraz od Narodowego Funduszu Ochrony Środowiska i Gospodarki Wodnej, Szczawnica znalazła się na liście rankingowej, na której umieszczono projekt o dofinansowanie przedsięwzięcia w wysokości 50\% jego wartości na kwotę 4.217.000 zł (Web-07).

Projekt „Solarna Szczawnica” objął zakup i instalację ok. 1600 kolektorów słonecznych. Przyczyniło się to do znaczącej poprawy jakości powietrza wynikającej z ograniczenia zużycia węgla o 50\%, oleju opałowego o 25\% oraz energii elektrycznej o 25\% (Web-08). Konsekwencją ograniczenia spalania paliw kopalnych jest znacząca redukcja emisji: „pyłu o 17,358 Mg/rok; dwutlenku siarki o 13,956 Mg/rok; dwutlenku azotu o $1,736 \mathrm{Mg} / \mathrm{rok}$; tlenku węgla o $37,96 \mathrm{Mg} / \mathrm{rok}$; dwutlenku węgla o $1957,512 \mathrm{Mg} / \mathrm{rok}$; sadzy o $0,875 \mathrm{Mg} / \mathrm{rok}$; BAP o $0,012 \mathrm{Mg} / \mathrm{rok}$ " (tamże). W wyniku realizacji projektu Szczawnica może pochwalić się czystszym powietrzem, co ma kluczowe znaczenie dla miejscowości uzdrowiskowej. Ponadto mieszkańcy korzystający z kolektorów cieszą się z niższych rachunków za ogrzewanie wody.

Działania w zakresie ochrony klimatu zostały przeprowadzone przy dużym wsparciu i zaangażowania społeczności lokalnej, która aktywnie brała udział w realizowaniu projektu jednocześnie stając się jego bene- 
ficjentem. Powyższy przykład pokazuje nie tylko, że działania na rzecz ochrony obszarów atrakcyjnych turystycznie są możliwe, ale również pokazuje jak współpraca władz samorządowych i mieszkańców może przyczynić się do wspólnego dbania o czystość powietrza i ograniczanie emisji w sposób uwzględniający sferę społeczną, ekonomiczną i środowiskową.

Działania na rzecz ochrony klimatu są też podejmowane przez liczne hotele, hostele czy schroniska, które we wprowadzaniu rozwiązań pro środowiskowych widzą nie tylko aspekt środowiskowy, ale także dostrzegają ekonomiczne i marketingowe walory. Kadra zarządzająca i projektująca tego typu obiekty zwraca coraz większą uwagę na ich energooszczędność poprzez odpowiedni dobór sprzętu RTV i AGD, termomodernizację budynków, zapewnienie, że dom obiekt będzie pochłaniał jak najwięcej ciepła z zewnątrz czy korzystanie z instalacji energetyki odnawialnej.

Jeden z ekologicznych hoteli w Poznaniu został specjalnie zaprojektowany i urządzony w sposób zapewniający minimalizację zużycia energii elektrycznej. Rozwiązania zastosowane w tym obiekcie są na tyle skuteczne, że hotel przy pełnym oświetleniu zewnętrznym i wewnętrznym pobiera tylko tyle energii elektrycznej co czajnik bezprzewodowy. Do niskiego zużycia energii przyczynia się tam również szereg energooszczędnych rozwiązań jak chociażby wykonanie elewacji z materiałów zapewniających minimalne straty ciepła czy podgrzewanie wody przez kolektory słoneczne.

Ciekawym przykładem działań w zakresie ograniczania emisji i troski o ochronę klimatu są działania Polskiego Towarzystwa Turystyczno-Krajoznawczego. PTTK podejmuje liczne starania, aby zwiększyć wykorzystanie nowoczesnych technologii tak, by obiekty PTTK były bardziej energooszczędne i przyjazne środowisku. Dzięki staraniom tej instytucji i wsparciu ze środków Norweskiego Mechanizmu Finansowego udało się zainstalować instalacje odnawialnych źródeł energii w wielu obiektach PTTK na przykład w Bieszczadach i Beskidzie Niskim. 
W ramach projektu zaplanowano następujące inwestycje:

- „Schronisko- Bacówka Kremenaros w Ustrzykach Górnych - montaż 95m² kolektorów słonecznych;

- Schronisko w Komańczy - montaż 72m² kolektorów słonecznych;

- Schronisko- Bacówka Pod Honem w Cisnej - montaż 54m² kolektorów słonecznych;

- Dom Wypoczynkowy w Wetlinie - montaż 140m² kolektorów słonecznych;

- Hotel Górski w Wetlinie - montaż $27 \mathrm{~m}^{2}$ kolektorów słonecznych;

- Hotel Górski i Camping nr 150 w Ustrzykach Górnych - montaż $27 \mathrm{~m}^{2}$ kolektorów słonecznych;

- instalacja pompy ciepła o mocy ok. 120kW zapewniającej ciepło do celów c.o. i c.c.w. oraz rurociągu glikolowego;

- Schronisko-Bacówka JAWORZEC w Jaworcu - montaż $54 \mathrm{~m}^{2}$ kolektorów słonecznych;

- instalacja hybrydowej elektrowni z turbiną wiatrowa i panelami fotowoltaicznymi" (Web-10).

Organizatorzy wypoczynku coraz bardziej zwracają uwage na pro środowiskowe rozwiązania, które przyczyniają się do ograniczania emisji i ochrony klimatu. Chociaż należy zaznaczyć, że często motywacją do tego typu działań nie jest troska o środowisko naturalne, badania prowadzone w tym zakresie pokazują, że zaledwie 30\% ankietowanych w tego typu działaniach kieruje się troską o ograniczenie oddziaływania na środowisko. Inspiracją do tego typu działań są również: obniżenie kosztów - 24\% ankietowanych; korzyści marketingowe - 19 \% czy lepszy wizerunek i reputacja obiektu - 19\% (Web-09).

Wszystkie te inwestycje przyczyniają się do ograniczenia zużycia węgla czy olei opałowych zużywanych do ogrzewania obiektów i wody, a co za tym idzie wiąże się to ze znaczącym ograniczeniem emisji gazów cieplarnianych. Te działania mają wpływ na jakość powietrza i na ochronę klimatu przyczyniając się do podnoszenia jakości środowiska. 
Zmiany klimatu a zrównoważona turystyka...

\section{Etyczny wymiar zrównoważonej turystyki}

Zmiany klimatu są jedną z przesłanek przemawiających za wprowadzaniem zrównoważonej turystyki, niemniej zrównoważona turystyka powinna być również postrzegana przez pryzmat etycznego wymiaru jej wdrażania. Wprowadzanie zrównoważonej turystyki powinno być postrzegane jako realizacja moralnych zobowiązań człowieka, jako dostrzeżenie i wyraz troski o dobrostan środowiska oraz organizmów żywych jak i o drugiego człowieka. W turystyce już od dawna dostrzega się potrzebę uwzględniania sfery etycznej w działalności turystycznej, stąd 30 października 1999 roku Zgromadzenie Ogólne Światowej Organizacji Turystyki (WTO), w specjalnej rezolucji (A/RES/406 (XIII)) przyjęło Globalny Kodeks Etyczny. Kodeks składa z preambuły, dziewięciu zasad oraz z mechanizmu jego wdrażania zawartego w artykule 10. Kodeks obejmuje sferę ekonomiczną, społeczną i kulturową płaszczyznę turystyki, uwzględniając następujące obszary:

Artykuł 1. Udział turystyki w pogłębianiu wzajemnego zrozumienia i szacunku pomiędzy narodami i społeczeństwami.

Artykuł 2. Turystyka jako narzędzie indywidualnej i zbiorowej samorealizacji.

Artykuł 3. Turystyka jako czynnik zrównoważonego rozwoju.

Artykuł 4. Turystyka - użytkownikiem, ale i beneficjentem dziedzictwa kulturowego ludzkości.

Artykuł 5. Turystyka jako działalność przynosząca korzyści krajom i społecznościom przyjmującym turystów.

Artykuł 6. Obowiązki uczestników rozwoju turystyki.

Artykuł 7. Prawo do turystyki.

Artykuł 8. Swoboda ruchu turystycznego.

Artykuł 9. Prawa pracowników i przedsiębiorców branży turystycznej. Artykuł 10. Wprowadzanie zasad Globalnego Kodeksu Etyki w Turystyce (Web-05, Web-06).

Przyjęcie kodeksu jest całkowicie dobrowolne, ale mimo to coraz częściej praktykowane przez wiele biur podróży i operatorów tury- 
stycznych. Etyczny wymiar turystyki jest także realizowany poprzez włączanie wartości do sfery działań tego sektora, wśród wartości należy wymienić przynajmniej kilka, które są kluczowymi w dyskursie etyki środowiskowej. Jedną z najważniejszych wartości, które znajdują odzwierciedlenie w postulacie zrównoważonej turystyki jest odpowiedzialność za środowisko przyrodnicze uwzględniająca troskę o integralność środowiska naturalnego oraz konieczność zachowania jego zasobów i walorów dla przyszłych pokoleń. Postulat odpowiedzialności w wymiarze biocentrycznym został sformułowany przez Hansa Jonasa (Jonas 1995). Sformułował on imperatyw odpowiedzialności za wszystkie żywe organizmy próbując zapewnić możliwość ich przetrwania. Jonas sformułował zontologizowaną koncepcję odpowiedzialności, w której samo istnienie jest racją bycia przedmiotem odpowiedzialności. W ten sposób zasada odpowiedzialności ufundowana na ontologii stawia przed człowiekiem zadanie ochrony życia w każdej postaci. W filozofii Jonasa „nagie, faktyczne «jest» w sposób oczywisty zbiega się z jakimś "powinien»" (Jonas 1995: 233). Ufundowana na ontologii odpowiedzialność jest ochroną każdego bytu ożywionego z samej racji jego istnienia.

Odpowiedzialność konstytuuje podmiotowość człowieka (Picht 1981: 173). Człowiek współczesny nie może sobie pozwolić na zawężanie pola odpowiedzialności tylko i wyłącznie do siebie samego bądź do drugiego. Rozwój naukowo-techniczny poszerzył zakres odpowiedzialności i stawia przed człowiekiem nowe wyzwania jak chociażby odpowiedzialność za środowisko przyrodnicze oraz odpowiedzialność za możliwość istnienia i funkcjonowania przyszłych pokoleń. Odpowiedzialność w zrównoważonej turystyce integruje kluczowe sfery, na jakie turystyka wpływa i wyraża się w trosce interesariuszy o zachowanie integralności środowiska naturalnego oraz minimalizowanie negatywnego wpływu działań w tej sferze. Wyrazem odpowiedzialności jest wyjście poza spojrzenie na turystykę jako na źródło natychmiastowego dochodu, na rzecz dostrzeżenia długofalowych i ponad ekonomicznych korzyści, jakie przynosi ta forma rekreacji oraz uwzględnianie w ra- 
chunku ekonomicznym „kosztów” świadczeń ekosystemów, z których korzystają interesariusze. Zrównoważona turystyka stanowi płaszczyznę realizacji odpowiedzialności za drugiego, ale także rozszerza zakres odpowiedzialności na świat pozaludzki. Wymaga od człowieka również uwzględniania interesów przyszłych pokoleń i troski o ich możliwość korzystania z zasobów, ale także jest wyrazem odpowiedzialności za zachowanie środowiska w stanie niezniszczonym dla dobra wszystkich żyjących obecnie jak i tych, którzy się jeszcze nie narodzili.

Dopełnieniem odpowiedzialności jest szacunek wobec życia i wszystkich jego przejawów. Włączając w to poszanowanie praw osób zaangażowanych w sektorze usług turystycznych. W przypadku turystyki zrównoważonej etyka szacunku wobec życia ma bardzo szeroki zakres, jest nie tylko troską o ochronę wszelkiego życia, ale także będzie wiązała się z troską o okazywanie szacunku lokalnym mieszkańcom. „Jak na biały promień światła składają się różnobarwne promienie, tak etyka poszanowania życia zawiera w sobie wszystko, co składa się na etykę miłości, życzliwości, współcierpienia i współradości, postawy pokojowej, zdolności do przebaczania” (Schweitzer 1964: 52). Te wszystkie elementy powinny być przejawem szacunku wyrażanego w zrównoważonej turystyce, szacunek powinien stać się fundamentem na podstawie którego budowana jest płaszczyzna porozumienia między interesariuszami oraz powinien wyrażać się w działaniach wszystkich uczestników tej formy turyzmu.

Kluczowe znaczenie ma szacunek wobec ludności lokalnej, który wyraża się nie tylko w zatrudnianiu lokalnej społeczności do pracy w sektorze usług turystycznych, ale także w szacunku wobec lokalnych tradycji i prawa prywatności lokalnej społeczności. Zagrożeniem w tej sferze może być chociażby tzw. „utowarowienie” kultury. Tragicznym przykładem jest Hiszpańskie miasto Fuenterrabía (znane też pod nazwą Hondarribia), w którym co roku odbywa się Alarde (Podemski 2008: 63). Alarde jest odtworzeniem zwycięstwa mieszkańców Fuenterrabía nad Francuzami, w które zaangażowani są wszyscy mieszkańcy miasteczka, przez co zwyczajowo Alarde było ważnym wydarzeniem 
pozwalającym zjednoczyć społeczność lokalną. Jednak charakter tego święta został zmieniony odkąd w 1969 roku Hiszpańskie Ministerstwo Turystyki wpisało festiwal na listę atrakcji turystycznych, od tego czasu Alarde stał się komercyjnym widowiskiem, nastawionym na cele marketingowe. Przez silny nacisk na przyciąganie turystów i uczynienie święta atrakcyjnym dla nich festiwal stracił dla mieszkańców znaczenie i wewnętrzną wartość, a stał się wyreżyserowanym spektaklem odgrywanym dla turystów żądnych wrażeń. Powyższy przykład niewątpliwie nie jest odosobniony, ale pokazuje, że zarówno w przypadku wartości przyrodniczej jak i kulturowej, którą staje się atrakcja turystyczną należy zwrócić szczególną uwagę na to, aby nie naruszyć jej charakteru i uszanować tradycję lokalną jak i odczucia miejscowej ludności z nią związane.

Szacunek i odpowiedzialność zrodzone w sferze intelektualnej jak i wolitywnej prowadzą do sprawiedliwości, która w zrównoważonej turystyce realizuje się w co najmniej dwóch wymiarach czasowych. Jako skierowana ku przyszłości kluczowe znaczenie ma sprawiedliwość międzypokoleniowa, której wyrazem jest troska o zachowanie dóbr kulturowych oraz przyrodniczych dla przyszłych pokoleń, tak aby i one mogły mieć do nich dostęp. Rozważane w etycznym dyskursie nad odpowiedzialnością pytanie czy człowiek ma prawo pozbawiać następne pokolenia dostępu do zasobów tylko dlatego, że miał do nich dostęp przed nimi zyskuje tutaj odpowiedź w postaci próby ochrony tych zasobów i nie dopuszczenia do ich degradacji pod wpływem nadmiernego ruchu turystycznego.

Sprawiedliwość wyraża się też w czasie teraźniejszym poprzez zapewnienie, że nikt nie będzie dyskryminowany z powodu wykształcenia, wyznania, koloru skór czy statusu materialnego (Wigley D. C., Shrader-Frechette K. 1996). W tym kontekście sprawiedliwość wyraża się na wiele sposobów takich jak chociażby nie dopuszczanie, aby wygody turystów przyczyniały się do dyskomfortu ludności miejscowej, np. poprzez nadmierne wykorzystywanie wody na obszarach gdzie jest ona dobrem deficytowym pozbawiając tym samym dostępu do niej 
miejscową ludność. Jednak jednym z kluczowych i podkreślanych przez zrównoważoną turystykę postulatów jest zapewnienie dostępu do korzyści z usług turystycznych dla miejscowej ludności, tak aby również ona stawała się beneficjentem działalności prowadzonej w miejscu jej zamieszkania.

Wyżej zarysowane wartości realizują się tak na poziomie sfery intelektualnej, jako owoc przemyśleń i analiz filozoficznych, jak i są realizowane w sferze praktycznej, mając swoje odzwierciedlenie w działaniach, dla których są motywacją. Głównym motorem realizowania aksjologicznej płaszczyzny zrównoważonej turystyki zdaje się być dostrzeżenie wewnętrznej wartości chronionych w turystyce zrównoważonej dóbr takich jak chociażby środowisko przyrodnicze, czy wartość kulturowa. Prowadzi ona nieuchronnie do zrodzenia się postawy szacunku i odpowiedzialności. Szacunek i odpowiedzialność są wyrazem zrozumienia, iż te dobra są wartościowe nie ze względu na możliwość ich wykorzystania, czerpania korzyści z ich używania, ale posiadają wewnętrzną wartość, niezależną od naszej oceny owych dóbr. W takim ujęciu są postrzegane jako wartość sama w sobie.

Zagadnienie wewnętrznej wartości przyrody jest przedmiotem wielu analiz. Niestety często próby uzasadniania wewnętrznej wartości przyrody stają się sprzeczne same w sobie, gdyż racją uzasadniającą stają się argumenty instrumentalne czy utylitarystyczne. Tym samym przyroda staje się cenna i wartościowa jako użyteczna dla człowieka, filozofowie wpadający w tą pułapkę zdają się tkwić w antropocentrycznym modelu myślenia. Zdaniem Godfrey-Smith'a (za Wearing, Neil 2009: 18) tego typu argumenty można podzielić na cztery główne kategorie:

- Estetyczne/duchowe - przyroda jest wartością dostarczającą przeżyć estetycznych czy też źródłem odzyskiwania równowagi ducha.

- Biologiczne/związane z bioróżnorodnością - przyroda jest źródłem genetycznej różnorodności.

- Naukowe - wartość przyrody jest dostrzegana przez pryzmat jej roli w badaniach naukowych. 
- Sportowe - przyroda jest bezcenną płaszczyzną rozwoju turystyki i rekreacji.

Mimo, że te racje ochrony wysuwane są wyraźnie przez pryzmat ludzkich „korzyści” czerpanych z przyrody to nie należy ich odrzucać, stanowią one podstawę do poszerzenia aksjologicznego spojrzenia na środowisko przyrodnicze docelowo wychodząc poza utylitarystyczne ujęcie. Stwarza to podstawę, aby holistyczne podejście stało się płaszczyzną formułowania poglądów, które uwzględniają całościowy obraz świata, wyrażając troskę o środowisko przyrodnicze i formułując postulat ochrony przyrody ze względu na jej wrodzoną wartość.

We wdrażaniu zrównoważonej turystyki istotne jest przede wszystkim osobiste zaangażowanie interesariuszy, ale jednocześnie kluczowe znaczenie ma indywidualny system wartości oraz dominujące w danym społeczeństwie normy kulturowe (Durydiwka, Kowalczyk, Kulczyk 2010:33), te czynniki będą bowiem płaszczyzną do podejmowania decyzji, niekiedy jednak dają "zbyt dużo miejsca na dowolną interpretację" (Lansing, De Vries 2006: 83). Patrząc na to zagadnienie z tej perspektywy kluczowe znaczenie ma zrozumienie, przez jednostkę oraz społeczność, celu zrównoważonej turystyki jakim jest zapewnienie długookresowego i harmonijnego rozwoju przy zachowaniu równowagi pomiędzy płaszczyzną środowiskową, gospodarczą i społeczno-kulturową (Web-03). Tak jak Sokrates był przekonany, że niewłaściwe działania etyczne wywodzą się z niewiedzy, tak również tutaj widać wyraźnie, iż zrozumienie i wiedza o założeniach zrównoważonej turystyki oraz długofalowych korzyściach wynikających z ich zastosowania mają kluczowe znaczenie. Istotne może być zrozumienie że w perspektywie długofalowej zrównoważona turystyka przynosi wszystkim korzyści, a masowa turystyka może przyczyniać się do zmian środowiska jak i do trwałej degradacji obszarów cennych ze względu na walory przyrodnicze i/lub kulturowe. Istotne ma też upowszechnianie wiedzy o etycznym wymiarze troski o środowisko, które może stać się fundamentem osobistego systemu przekonań wzmacniający tym samym pozytywne zmiany zachowań. 
Pojawia się jednak pytanie, czy ten „etyczny” wymiar zrównoważonej turystyki jest wyrazem dostrzegania moralnych zobowiązań czy tylko etyczną opakowaniem tradycyjnych usług i produktów, a przez to sprytną strategią marketingową. „Etyczna „otoczka” nie musi wcale wiązać się z wysoką świadomością organizatorów tej formy wypoczynku, a może niekiedy być przykładem wysokiego poziomu motywacji do zdobycia zysku nawet kosztem wprowadzania w błąd turystów" (Dzwonkowska 2011: 36). Obserwacja atrakcji turystycznych i systemowa ocena prowadzonej przez nie działalności doprowadziła do zdemaskowania wielu niechlubnych przypadków, w których „etyczność” usług turystycznych ograniczała się tylko do nazwy określającej je jako takie. Jednak warto podkreślać, że jest również wiele przykładów, gdzie program „etycznej” turystyki jest realizowany i gdzie przynosi nie tylko korzyści finansowe. Jak zauważa Fleckenstein bycie etycznym to dobry interes „ponieważ bycie etycznym powiększa zyski firmy, wydajność zarządu, poprawia wizerunek publiczny i relacje między pracownikami” (Fleckenstein, Huebsch 1999: 137). Stąd zmiana w tym sektorze jest nie tylko konieczna ze względu na ryzyko zniszczenia środowiska przez tradycyjną turystykę czy zachodzące zmiany klimatu, ale także pojawia się jako szansa na poprawienie jakości usług i pracy w tym sektorze.

\section{Zakończenie}

Holistyczny rozwój człowieka zakłada równoważenie aktywności w sferze pracy zawodowej jak i w sferze właściwie pojętej rekreacji. Obecnie turystyka jest jedną z najatrakcyjniejszych form spędzania czasu wolnego i oferuje szereg możliwości spędzenia wolnego czasu w sposób atrakcyjny i przyjemny, a nawet stwarza możliwość łączenia odpoczynku ze zdobywaniem nowej interesującej poznawczo wiedzy ${ }^{3}$. Jednak turystyka i podróżowanie nie powinno być traktowane jako

Na rynku usług turystycznych pojawia się dużo ofert skierowanych do osób zainteresowanych poszerzaniem swojej wiedzy, np. szlaki literackie zachęcające do podróżowania śladami znanych poetów czy pisarzy (np. szlak Agaty Christie) bądź śladami bohaterów literackich (np. szlak Don Kichota czy Wokulskiego). 
odpoczynek od wartości (Ostrowski 2008: 111). Wręcz przeciwnie zrównoważona turystyka nie tylko zrodziła się z dostrzeżenia zagrożeń wynikających $z$ antropopresji, ale także jest płaszczyzną realizowania wartości moralnych. Zmiany klimatu są postrzegane jako obszar, gdzie konieczna jest refleksja etyczna, ich wpływ na sektor turystyczny pozwala dostrzec skalę antropopresji na środowisko naturalne. Zrównoważona turystyka zdaje się być rozwiązaniem idealnie godzącym troskę o środowisko, społeczeństwo i wymiar ekonomiczny, który nie tylko godzi te sfery, ale także jest odpowiedzią na dotychczasowy deficyt moralny panujący w tej sferze.

Wprowadzenie zasady zrównoważonego rozwoju do turystyki jest wyrazem odpowiedzialności i troski o środowisko naturalne, o drugiego oraz wobec możliwości przyszłych pokoleń do korzystania z obszarów cennych ze względu na walory przyrodnicze i kulturowe. Zrównoważona turystyka daje możliwość wyrażania szacunku wobec życia we wszystkich jego przejawach, wyrażając się w trosce o integralność obszarów przyrodniczych jak i troską w sferze społecznej o dobrobyt miejscowej ludności i poszanowanie praw wszystkich uczestników tego sektora usług. Zrównoważona turystyka stwarza także możliwość realizowania wartości sprawiedliwości, która jest wyraża się w trosce o zapewnienie dobra obecnych uczestników turyzmu oraz o dobro przyszłych uczestników tej sfery aktywności ludzkiej. Kryzys ekologiczny wynika z zachwiania porządku moralnego dlatego też wyzwaniem stojącym przed człowiekiem współczesnym jest dostrzeżenie swoich zobowiązań wobec środowiska przyrodniczego i wobec drugiego oraz realizacja ich na różnych płaszczyznach włącznie ze sferą rekreacji.

\section{Bibliografia}

\section{Literatura:}

Bigano A., Hamilton J.M., Tol R.S.J., 2006, The impact of climate change on domestic and international tourism: A simulation study, Fondazione Eni Enrico Mattei 86. 
Durydiwka M., Kowalczyk A., Kulczyk S., 2010, „Definicja i zakres pojęcia <<turystyka zrównoważona>>”, w: Kowalczyk A. (red.), Turystyka zrównoważona, PWN, Warszawa, s. 21-43.

Dzwonkowska Dominika, Zasada zrównoważonego rozwoju w turystyce, Studia Ecologiae et Bioethicae 9(2011)2, s. 23-41.

EEA, 2007, Europe's Environment: the fourth assessment, Kopenhaga.

EEA, 2007, European bathing water quality in 2011, Kopenhaga.

Fleckenstein M.P., Huebsch P., 1999, Ethics in Tourism-Reality or Hallucination, Journal of Business Ethics 19, s. 137-142.

Freitas C.R., 2003, Tourism climatology: evaluating environmental information for decision making and business planning in the recreation and tourism sector, International Journal of Biometeorology, (2003) 48, s. 45-54.

Jonas H., 1994, "Philosophy at the end of the century: a survey of its past and future", Social Research, 61(1994)4.

Jonas H., 1995, Zasada odpowiedzialności, PLATAN, Kraków.

Koening U., Abegg B., 1997, Impacts of climate change on winter tourism in the Swiss Alps, Journal of Sustainable Tourism, 5 (1), s. 46-58.

Lansing P., De Vries P., 2006, "Sustainable tourism : ethical alternative or marketing ploy?", Journal of Business Ethics, No. 73, 77-85.

Mishev P., Mochurova M., 20102, Impacts of Climate Change on Tourism, w: V. Alexandrov i in. (red.), "Global Environmental Change: Challenges to Science and Society in Southeastern Europe, DOI 10.1007/978-90-481-8695-2_15, 193-200.

Ostrowski M., 2008, „Teologia turystyki”, w: Winiarski R. (red.), Turystyka w naukach humanistycznych, PWN, Warszawa, 102-116.

Picht G., 1981, „Odwaga utopii”, w: Odwaga utopii, PIW, Warszawa.

Renan E., 2002, „Przyszłość nauki”, w: Skarga B. (red.),, Renan, Wiedza Powszechna, Warszawa.

Schweitzer A., 1964, Życie, PAX, Warszawa.

Wearing S., Neil J., 2009, Ecotourism - impact, potentials and possibilities, ButterworthHeinemann, Oxford.

Wigley D. C., Shrader-Frechette K., 1996, "Environmental Justice: A Louisiana Case Study", Journal of Agricultural and Environmental Ethics, No. 9, 61-82.

Zaręba D., 2010, Ekoturystyka, PWN, Warszawa.

\section{Witryny internetowe:}

(Web-01) Bacon F., The New Organon, <http://www.constitution.org/bacon/nov_org. htm>, dostęp: 15.12.2011.

(Web-02) Hardin G., The tragedy of the commons, <http://www.sciencemag.org/content/162/3859/1243.full>, dostęp: 12.01.2011. 
(Web-03) Sustainable Development of Tourism, <http://www.unwto.org/sdt/mission/ en/mission.php?op=1, dostęp: 10.12.2010.

(Web-04) http://www2.unwto.org/, dostęp: 04.02.2013.

(Web-05) Globalny kodeks etyki w turystyce, <http://www.umww.pl/pub/uploaddocs/ biura-podrozy-globalny-kodeks-etyki.1346222157.pdf>, dostęp: 11.02.2013.

(Web-06) Global Code of Ethics for Tourism, <http://ethics.unwto.org/en/content/global-code-ethics-tourism>, dostęp: 11.02.2013.

(Web-07) Solarna Szczawnica, <http://www.globenergia.pl/kolektory-s\%C5\%82oneczne/item/2086-solarna-szczawnica.html>, dostęp: 18.03.2013.

(Web-08) <http://www.eko.org.pl/klimat/index_dzialania.php?dzial=4\&kat=11\&art=13>, dostęp: 18.03.2013.

(Web-09) <http://ecohotelpolska.blogspot.com/2009/07/hotele-ekologiczne.html>, dostęp: 18.03.2013.

(Web-10) <http://www.bieszczadypttk.pl/inwestycje-w-obiektach.html>, dostęp: 18.03.2013. 